ROCZNIKI NAUK SPOŁECZNYCH

Tom 11(47), numer 3 - 2019

DOI:http://dx.doi.org/10.18290/rns.2019.11.3-4

\title{
NAUCZANIE RELIGII W SZKOLE W OPINIACH I OCENACH POLSKIEGO SPOŁECZEŃSTWA
}

\section{WPROWADZENIE}

Po upadku komunizmu w 1989 roku następowały w Polsce zmiany społeczne, których celem było wprowadzenie standardów demokratycznych i zbudowanie społeczeństwa obywatelskiego. Jednym z ważnych przedsięwzięć stało się przywrócenie zasady wolności religijnej, która miała zagwarantować obywatelom swobodę wyznawania religii. Realizacja tych zamierzeń wiązała się ze zmianą obowiązującego prawa, gdyż w okresie PRL władze komunistyczne administracyjnie ograniczały wolność religijną obywateli oraz szykanowały Kościół katolicki, którego wyznawcy stanowili ponad $90 \%$ ogółu społeczeństwa polskiego ${ }^{1}$. Zamiarem rządzącej w Polsce partii było sprawowanie władzy totalnej nad wszystkimi wymiarami życia społecznego, w tym nad wychowaniem młodego pokolenia. Zachowanie monopolu w ideologicznym kształtowaniu świadomości społecznej wiązało się z eliminowaniem wpływu Kościoła na edukację dzieci i młodzieży². Komuniści, nie licząc się z głosem społeczeństwa, przez niemal

Ks. dr hab. WITOLD JEDYNAK, prof. UR - Instytut Socjologii Uniwersytetu Rzeszowskiego; adres do korespondencji: Al. Rejtana 16 C, 35-959 Rzeszów; e-mail: vox321@interia.pl

${ }^{1}$ A. AnUSZ, A. ANUSZ, Samotnie wśród wiernych. Kościót wobec przemian politycznych w Polsce (1944-1994), Wydawnictwo Alfa, Warszawa 1994, s. 25; S. MurZAŃSKI, PRL zbrodnia niedoskonata: rozważania o terrorze władzy i społecznym oporze, Oficyna Wydawnicza Volumen, Wydawnictwo Alfa-Wero, Warszawa 1996, s. 153-162; Z. ZIELIŃSKI, Kościót w Polsce 1944-2002, Polskie Wydawnictwo Encyklopedyczne, Radom 2003, s. 55.

${ }^{2}$ M. TARNIEWSKI [czytaj J. Karpiński], Ewolucja czy rewolucja, Instytut Literacki, Paryż 1975, s. $115-118$. 
pół wieku prowadzili wobec Kościoła katolickiego represyjną politykę wyznaniową opartą na założeniach ideologii marksistowskiej oraz stosowali opresyjne prawo wyznaniowe. Jednym z elementów walki ideologicznej było całkowite usunięcie nauczania religii ze szkół publicznych ${ }^{3}$.

Przemiany ustrojowe po upadku komunizmu w Polsce stworzyły dogodne warunki umożliwiające powrót nauczania religii do szkół publicznych. Dlatego też przedstawiciele hierarchii kościelnej oraz katolicy świeccy, odwołując się do demokratycznych standardów społeczeństw obywatelskich obowiązujących w krajach Europy Zachodniej, apelowali do władz państwowych o przywrócenie nauczania religii do szkół, z których została siłowo usunięta przez reżim komunistyczny. Środowiska kościelne uważały, że powrót nauczania religii do szkół będzie naprawieniem jednej z wielu krzywd, jakie spotkały społeczeństwo ze strony systemu totalitarnego ${ }^{4}$.

We wrześniu 1990 r. pierwszy niekomunistyczny rząd polski zdecydował o wprowadzeniu nieobowiązkowego nauczania religii do szkół publicznych. W szkołach podstawowych decyzję o udziale dzieci w lekcjach religii podejmowali rodzice, natomiast w szkołach średnich wyboru dokonywali zazwyczaj sami uczniowie ${ }^{5}$. Zajęcia odbywały się w wymiarze dwóch godzin lekcyjnych tygodniowo i były prowadzone tylko przez osoby posiadające skierowanie od biskupa diecezjalnego. Katecheci na równi z innymi nauczycielami wchodzili w skład rady pedagogicznej. Uczniowie, którzy nie chcieli uczestniczyć w katechezie szkolnej, mogli wybrać zajęcia z etyki ${ }^{6}$.

Reaktywowanie nauczania religii w szkołach publicznych umożliwiło dzieciom i młodzieży powszechny dostęp do korzystania $\mathrm{z}$ formacji religijnej

${ }^{3}$ A. DudeK, R. Gryz, Komuniści i Kościót w Polsce (1945-1989), Wydawnictwo Znak, Kraków 2006, s. 159-161; S. BOBER, Walka o utrzymanie nauczania religii w szkołach $w$ okresie Polski Ludowej, „Studia Ełckie” 14(2012), s. 196-197; S. SKUZA, Nauczanie religii w Polsce w świetle prawa państwowego po roku 1945, „Kolekcja Communio” 8(1993), s. 242.

${ }^{4}$ EPISKOPAT POLSKI, Komunikat 240 Konferencji Plenarnej Episkopatu Polski (Warszawa, 2.05.1990 r.), w: Komunikaty Konferencji Episkopatu Polski 1945-2000, opr. J. Żaryn, Sekretariat Konferencji Episkopatu Polski, Pallottinum, Warszawa-Poznań 2006, s. 355; EPISKOPAT POLSKI, List pasterski Episkopatu Polski w sprawie powrotu katechizacji do szkoty polskiej (Kraków, 16.06.1990 r.), w: Listy pasterskie Episkopatu Polski 1945-2000, cz. 2, red. P. Libera, A. Rybicki, S. Łącki, Wydawnictwo Michalineum, Marki 2003, s. 1651-1652.

${ }^{5}$ L. AdAmCzuK, Nauczanie religii w Polsce 1945-1999, w: Kościót i religijność Polaków 1945-1999, red. W. Zdaniewicz, T. Zembrzuski, Instytut Statystyki Kościoła Katolickiego SAC, Warszawa 2000, s. 242; R. CZEKALSKI, Rys historyczny lekcji religii katolickiej w Polsce, „Studia Katechetyczne” 7(2010), s. 122-123.

${ }^{6}$ J. SzPET, Vademecum Katechety, Księgarnia Świętego Wojciecha, Poznań 2000, s. 7. 
i moralnej ${ }^{7}$. Jednak nie wszystkie siły polityczne chciały się z tym faktem pogodzić. Lekcje religii w szkole wywoływały emocjonalne spory ideologiczne, zwłaszcza między przedstawicielami zwalczających się partii politycznych i stawały się przedmiotem długoletnich polemik, podczas których ich zwolennicy i przeciwnicy przywoływali argumenty na uzasadnienie swoich racji. Niestety, w sporze tym politycy kierowali się często jedynie własnymi przekonaniami światopoglądowymi, natomiast nie wsłuchiwali się w głos społeczeństwa polskiego, a zwłaszcza swoich wyborców i nie uwzględniali jego opinii. Wielu z nich używało populistycznych argumentów, a przywrócenie religii do szkół przedstawiało jako jeden z wielu przykładów dążenia Kościoła do klerykalizacji i stworzenia państwa wyznaniowego ${ }^{8}$.

Przedmiotem badań, zrealizowanych przez autora niniejszego opracowania, jest nauczanie religii w polskich szkołach, natomiast celem analiza oraz interpretacja opinii na jego temat. Autor w oparciu o źródła zastane przedstawi wyniki ogólnopolskich, reprezentatywnych badań socjologicznych odnoszących się do nauczania religii w szkołach. Ponadto spróbuje ustalić, na ile nauczanie religii, realizowane w polskich szkołach od 1990 roku, odpowiada oczekiwaniom społecznym, a zwłaszcza wymaganiom uczniów uczestniczących w lekcjach religii. Przedstawi także różne stanowiska dotyczące obecności religii w szkole publicznej. Podejmie też próbę ustalenia poziomu poparcia społecznego dla nauczania religii w szkole. Ponieważ lekcje religii w polskich szkołach mają charakter konfesyjny będą w niniejszej publikacji nazywane również katechezą szkolną.

\section{IDEOLOGICZNE I POLITYCZNE PODŁOŻE SPORÓW O NAUCZANIE RELIGII W SZKOLE}

Przywrócenie nauczania religii do polskich szkół publicznych było przez niektóre środowiska lewicowe i liberalne oceniane jako posunięcie antymodernizacyjne, czy nawet antydemokratyczne. Lekcje religii w szkole traktowano

\footnotetext{
${ }^{7}$ R. BEDNARCZYK, Efektywność szkolnej lekcji religii w perspektywie „filarów wiary”, w: Nauczanie religii w szkole w latach 1990-2015 wobec zadań katechezy, red. A. Rayzacher-Majewska, Wydawnictwo Uniwersytetu Kardynała Stefana Wyszyńskiego w Warszawie, Warszawa 2016, s. 13-14; A. RAYZACHER-MAJEWSKA, Wychowawcze zadania katechezy w szkolnym nauczaniu religii, w: Nauczanie religii w szkole w latach 1990-2015 wobec zadań katechezy, s. 87-88.

8 J. Gowin, Kościót w czasach wolności 1989-1999, Wydawnictwo Znak, Kraków 1999, s. $44,106$.
} 
jako formę socjalizacji moralnej, opartej na motywacji religijnej. Przeciwnicy religii w szkole odwoływali się do praktyki państw wysoko rozwiniętych, które od dziesięcioleci odchodziły w nauczaniu szkolnym od socjalizacji moralnej, ograniczając tym samym wpływ Kościołów na wychowanie młodego pokolenia ${ }^{9}$. Wobec sekularyzacyjnych tendencji w społeczeństwach zachodnioeuropejskich powrót nauczania religii do polskich szkół stał się obiektem polemik, generującym ambiwalentne postawy. W ferworze walki ideologicznej środowiska liberalne i lewicowe zdawały się nie zauważać, że wyznaniowe nauczanie religii jest standardowym procesem edukacyjnym $\mathrm{w}$ wielu państwach europejskich o ugruntowanej demokracji ${ }^{10}$.

Podstawy prawne nauczania religii w polskich szkołach były zaskarżane do Trybunału Konstytucyjnego jako pozostające w sprzeczności z obowiązującym w Polsce ustawodawstwem. W skardze podnoszono, że naruszają świecki charakter szkoły, a zwłaszcza zasadę wolności sumienia i wyznania. Kwestionowano również tryb wydania tych aktów prawnych. Trybunał Konstytucyjny uznał złożone skargi za bezzasadne i je oddalił ${ }^{11}$.

Pomimo iż postanowienia Trybunału Konstytucyjnego były jednoznaczne, nie przekonały oponentów katechezy szkolnej. Skoro nie udało się im podważyć podstaw prawnych przywrócenia nauczania religii do polskich szkół, usiłowali spory ideologiczne przenieść - za pomoca mediów - na poziom dyskursu społecznego, a zwłaszcza wciągnąć w nie rodziców i uczniów. Lewicowe media przedstawiały religię w szkole jako zagrożenie dla neutralności światopoglądowej polskiej edukacji. Jednocześnie przekonywały, iż „na katechezę uczęszcza niewielu młodych Polaków (od 20 do 50\%)", spośród których znaczna część przychodzi jedynie po to, aby prowadzić spory ideologiczne $\mathrm{z}$ uczącymi religii kapłanami ${ }^{12}$.

\footnotetext{
${ }^{9}$ K. KosEŁA, Religia przy tablicy - postawy wobec lekcji religii w szkołach, w: Szkoła czy parafia? Nauka religii $w$ szkole $w$ świetle badań socjologicznych, red. K. Kiciński, K. Koseła, W. Pawlik, Zakład Wydawniczy Nomos, Kraków 1995, s. 100.

${ }^{10} \mathrm{P}$. TOMASIK, Nauczanie religii $w$ szkołach publicznych $w$ Europie, ,Studia Katechetyczne" 7(2010), s. 48-53.

11 A. DudeK, Historia polityczna Polski 1989-2005, wyd. 1, Wydawnictwo Arcana, Kraków 2007, s. 157-158; M. KINAL, Teaching of religion in polish schools after 1989, w: Sociology of Religion. Selected aspects from Central European Region, red. W. Jedynak, J. Kinal. D. Luźny, D. Topinka, Advert, Rzeszów 2016, s. 122; W. PAWLIK, Nauka religii w szkole jako problem polityczny, w: Szkoła czy parafia? Nauka religii w szkole w świetle badań socjologicznych, s. 31-35.

12 G. TOKARZ, Polska prasa lewicowa wobec Kościoła katolickiego w latach 1989-2002, b.w., Wrocław 2004, s. 149. Zob. A. LEPA, Świat propagandy, wyd. 1, Tygodnik Katolicki „Niedziela”, Częstochowa 1994, s. 84-90.
} 
Dla zwolenników demokracji liberalnej wpływ Kościoła - będącego niepolityczną instytucją zorganizowaną według nieliberalnych zasad - na wychowanie młodego pokolenia wydawał się sprzeczny z zasadą wolności jednostki i neutralności światopoglądowej państwa. Liberalizm odrzuca bowiem absolutną prawdę jako konieczną podstawę kooperacji w społeczeństwie, przyznając jednocześnie jednostkom niezbywalne uprawnienia i postulując zniesienie wszelkich ograniczeń, byleby stan ten nie stanowił zagrożenia dla innych jednostek. W liberalnym społeczeństwie nie ma więc jednej koncepcji dobra, nie ma też jednolitej moralności, lecz ścierają się różne moralności, a wynikające $\mathrm{z}$ tego różnice i konflikty są stanem chronicznym i koniecznym ${ }^{13}$.

Pomiędzy zwolennikami nauczania religii w szkole a jego przeciwnikami rozgorzał permanentny spór, w którym strony konfliktu przedstawiały argumenty „za” i „przeciw”. Środowiska domagające się usunięcia religii ze szkół podnosiły przede wszystkim racje ideologiczne, które - w ich ocenie - wynikają z neutralności światopoglądowej państwa demokratycznego. Oponenci twierdzili, iż katecheza w szkołach publicznych narusza demokratyczną zasadę rozdziału Kościoła od państwa. Szkoły, mające charakter świecki, nie mogą stawać się miejscem wyznaniowej indoktrynacji, której celem jest utrwalanie wiary religijnej młodych ludzi oraz włączanie ich w życie religijne społeczności wyznaniowych. Szkoła publiczna ma bowiem edukować, przekazując uczniom wiedzę i kształtując humanistyczne postawy. Nauczanie religii nie należy do zadań edukacyjno-wychowawczych neutralnej światopoglądowo szkoły świeckiej. Kształtowanie przekonań religijnych pozostaje w kompetencjach Kościoła, który za własne środki finansowe ma realizować swoje wyznaniowe cele w należących do niego obiektach. Kościół nie może przerzucać na szkołę odpowiedzialności za organizowanie i finansowanie wyznaniowej edukacji religijnej. Katechizacja powinna być finansowana ze źródeł kościelnych ${ }^{14}$.

Przeciwnicy edukacji religijnej zgłaszali zastrzeżenia formalno-prawne do trybu wprowadzenia nauczania religii do szkół, który - ich zdaniem - był niewłaściwy, niedemokratyczny, gdyż nie poprzedzono go konsultacjami społecznymi, a zwłaszcza nie uwzględniono opinii rodziców i uczniów. Siłowe wprowadzenie nauczania religii do szkół publicznych było przejawem nadużywania władzy przez Kościół katolicki w polskim społeczeństwie ${ }^{15}$. Twier-

\footnotetext{
13 J. SzACKI, Liberalizm po komunizmie, wyd. 1, Społeczny Instytut Wydawniczy Znak, Fundacja im. Stefana Batorego, Kraków 1994, s. 241-243.

14 J. BANIAK, O nauczaniu religii $i$ etyki $w$ szkole, http://www.kulturaswiecka.pl/node/641 (dostęp 09.12.2017).

${ }^{15}$ K. KICIŃSKI, Religia w szkole: argumenty za i przeciw, Szkoła czy parafia? Nauka religii $w$ szkole $w$ świetle badań socjologicznych, s. 80; J. BANIAK, O nauczaniu religii.
} 
dzono, iż religia w szkołach jest przejawem klerykalizacji życia publicznego, a także formą indoktrynacji, ponieważ uprzywilejowuje jedno wyznanie i jednocześnie dyskryminuje inne religie. Ponadto negatywnie oddziałuje na społeczności szkolne, gdyż wprowadza konflikty ideologiczne oraz podziały wśród uczniów, sprzyja nietolerancji i generuje antagonizmy na tle światopoglądowym ${ }^{16}$

Natomiast zwolennicy nauczania religii w szkole nie ograniczali swojego poparcia jedynie do przedstawiania argumentów ideologicznych, lecz zwracali również uwagę na praktyczne i organizacyjne zalety katechezy szkolnej. Przekonywali, że jest ona ważnym osiągnięciem demokracji europejskiej szanującej wolność sumienia i wyznawania religii. Daje bowiem możliwość swobodnego nauczania i wychowania zgodnego z osobistymi zapatrywaniami światopoglądowymi. Umożliwia korzystanie $\mathrm{z}$ wolności religijnej rodzicom, którzy maja prawo do wychowania dzieci zgodnie ze swoimi przekonaniami nie tylko w domu rodzinnym, ale również w szkołach. Konfesyjne nauczanie religii $\mathrm{w}$ szkole jest jedną $\mathrm{z}$ form realizacji prawa rodziców do wychowania religijnego lub filozoficznego dzieci ${ }^{17}$.

Wyrażając zgodę na prowadzenie katechizacji w szkołach publicznych państwo polskie zapewnia ochronę wolności do uzewnętrzniania przekonań religijnych przez obywateli $\mathrm{w}$ życiu prywatnym i publicznym ${ }^{18}$. Ponadto lekcje religii w szkole wpisują się w polską tradycję, której ciągłość została przerwana przez represyjną politykę wyznaniową komunistów w PRL. Katecheza szkolna ma silne poparcie społeczeństwa polskiego w przeważającej większości katolickiego i odpowiada jego oczekiwaniom ${ }^{19}$.

\footnotetext{
${ }^{16}$ L. AdAmCZuK, Nauczanie religii w Polsce, s. 246; A. SzWAJKAJZER, Młodzież o lekcjach religii w szkole, w: Szkota czy parafia? Nauka religii w szkole, s. 149.

${ }^{17} \mathrm{~K}$. WIĘCEK, Nauczanie religii katolickiej w polskiej szkole publicznej w kontekście prawa rodziców do wychowania religijnego dzieci - aspekty historyczne i wybrane aktualne problemy, „Studia z Prawa Wyznaniowego” 16(2013), s. 187; J. KRZYWKowSKA, Uregulowania prawne $i$ praktyka $w$ zakresie nauczania religii $w$ szkołach publicznych $w$ Polsce, „Studia Prawnoustrojowe" 2017, nr 38, s. 355.

${ }^{18}$ Ł. KASPER, A. WOJTAS, Nauczanie religii w szkole - zgodne z konstytucja i europejskimi standardami; http://www.katecheza.episkopat.pl/index.php/menu/nauczanie-religii-w-szkole /dokumenty-koscielne/104-nauczanie-religii-w-szkole-zgodne-z-konstytucja-i-europejskimi-stan dardami-2016 (dostęp 08.12.2017).

${ }^{19}$ K. KICIŃSKI, Religia w szkole, s. 79; A. SZWAJKAJZER, Młodzież o lekcjach religii w szkole, w: Szkoła czy parafia?, s. 148.
} 
Zwolennicy nauczania religii w szkołach zwracali uwagę na rolę katechezy w procesie socjalizacji. W ich ocenie, katecheza szkolna ma wartość wychowawczą i dydaktyczną. Podczas lekcji religii przekazuje się nie tylko uniwersalne zasady i normy etyczne, ale również ubogaca się młodego człowieka, podnosząc ogólny poziom jego wykształcenia oraz ucząc osobistej kultury ${ }^{20}$. Katecheza w szkole nie narusza niczyjej wolności religijnej, ponieważ jest przedmiotem nieobowiązkowym, którego nauczanie jest uzależnione od woli rodziców i uczniów. W przypadku braku zainteresowania katechezą, uczniowie mogą uczestniczyć w lekcjach etyki. Jeśli natomiast zdecydują się na udział w zajęciach z religii, mogą w niej uczestniczyć w budynku szkolnym, co zwiększa szansę na objęcie katechizacją większej populacji młodych ludzi. Dominacja nauczania religii katolickiej w polskich szkołach nie jest przejawem uprzywilejowania Kościoła katolickiego, ale pochodną struktury wyznaniowej społeczeństwa. Państwo nikogo nie zmusza do udziału w szkolnej katechezie, lecz uwzględnia wolę rodziców, którzy chcą, aby ich dzieci naukę religii bezpłatnie pobierały $\mathrm{w}$ szkole ${ }^{21}$.

Lekcje religii w szkole umożliwiają rodzicom i uczniom planowanie i sprawne organizowanie harmonogramu codziennych obowiązków. Odciążają od zajęć pozalekcyjnych i pozwalają zaoszczędzić czas, jaki uczniowie musieliby przeznaczyć na pokonanie drogi do kościołów czy punktów katechetycznych, nierzadko znacznie oddalonych od szkół. Poważny problem z przemieszczaniem, zwłaszcza w okresie zimowym, mieliby uczniowie najniższych klas szkoły podstawowej ${ }^{22}$.

Przywołane powyżej argumenty w sporach ideologicznych nie miały wpływu na stan prawny dotyczący nauczania religii w szkołach. Jest on określony w Konstytucji RP, w której zapisano, że religia kościoła lub związku wyznaniowego, mającego uregulowaną sytuację prawną, może być przedmiotem nauczania w szkole przy poszanowaniu wolności sumienia i religii innych osób $^{23}$. Ponadto w konkordacie zapisano, iż państwo polskie zobowiązało

${ }^{20}$ W. OsIal, Misja wychowawcza lekcji religii w szkole, „Warszawskie Studia Teologiczne" 25(2012), nr 2, s. 275-279; I. CELARY, Nauczanie religii w szkole szansa dla ewangelizacji młodzieży, „Perspectiva. Legnickie Studia Teologiczno-Historyczne” 10(2011), nr 1, s. 22.

${ }^{21}$ A. PотоскI, O Kościele także socjologicznie, Wydawnictwo Naukowe PWN, Warszawa 2017, s. 564-565; J. KRZYWKOWSKA, Uregulowania prawne, s. 362-364.

${ }^{22}$ K. KICIŃSKI, Religia w szkole, s. 79.

${ }^{23}$ Konstytucja Rzeczpospolitej Polskiej z 2 kwietnia 1997 r., art. 53, ust. 4, (Dz.U. 1997 nr 78 poz. 483; http://prawo.sejm.gov.pl/isap.nsf/download.xsp/WDU19970780483/U/D19970 483Lj.pdf (dostęp 15.12.2017). Zob. M. PISAREK, Obecność nauczania religii w publicznym systemie oświaty w świetle obowiazujacego prawa, Wydawnictwo i Drukarnia Diecezji Rze- 
się do organizowania nauczania religii w publicznych szkołach podstawowych i ponadpodstawowych oraz przedszkolach ${ }^{24}$.

Nie ulega wątpliwości, że działania o charakterze ideologicznym, wymierzone przeciwko przywróceniu nauczania religii do szkół, były wynikiem dynamicznych zmian na polskiej scenie politycznej po przełomie w 1989 roku. Wielu Polakom wydawało się, że „Solidarność”, która pod koniec lat osiemdziesiątych była poważną siła społeczno-polityczną, będzie budowała państwo na tradycyjnych wartościach i zasadzie dobra wspólnego. Jednak przedstawiciele „Solidarności” zawarli z komunistami porozumienie przy „okrągłym stole”, które wyznaczyło ideowy kierunek przemian systemowych w kraju, jakim była liberalna demokracja. Przyjęcie liberalnej demokracji, jako podstawy budowania społeczeństwa obywatelskiego, doprowadziło do rezygnacji rządu solidarnościowego z ideałów „Solidarności”. Demontaż solidarnościowego etosu, a zwłaszcza odcinanie się elit postsolidarnościowych od systemu wartości opartego na katolickiej nauce społecznej oznaczało nieuchronną zmianę nastawienia nowej władzy do religii katolickiej. Kościół, który jeszcze do niedawna był powszechnie uznawany za instytucję mającą olbrzymie zasługi w dążeniu do demokratyzacji życia społecznego, stał się obiektem licznych ataków ideologicznych. Po przełomie część elit politycznych i intelektualnych zmieniła diametralnie swój stosunek do Kościoła. Ludzie ci nie postrzegali już Kościoła jako sojusznika w stabilizowaniu demokracji, ale coraz częściej traktowali jako poważną przeszkodę w budowaniu liberalnego, otwartego i nowoczesnego społeczeństwa. Jednym z powodów działań wymierzonych w Kościół było przywrócenie nauczania religii do szkół publicznych ${ }^{25}$.

Podłoże sporów o nauczanie religii miało uwarunkowania społeczno-polityczne. Społeczeństwo polskie w porównaniu z innymi demokratycznymi społeczeństwami państw europejskich prezentuje konserwatywne poglądy i jest

szowskiej, Rzeszów 2013, s. 84; A. TYMIENIECKA, Nauczanie religii w szkołach publicznych, „Kortowski Przegląd Prawniczy” 2015, nr 1, s. 92.

${ }^{24}$ Konkordat między Stolicą Apostolską i Rzeczypospolitą Polską, podpisany w Warszawie dnia 28 lipca 1993 r., art 12, ust. 1-4 (Dz.U. $1998 \mathrm{nr} 51$ poz. 318); http://prawo.sejm.gov.pl/isap. nsf/DocDetails.xsp?id=WDU19980510318 (dostęp 15.12.2017). Zob. B. TRZECIAK, Relacja państwo -Kościót. O polskim Konkordacie '93, Oficyna Wydawnicza Kontrast, Warszawa 1998, s. 92; M. PISAREK, Obecność nauczania religii, s. 101; A. TYMIENIECKA, Nauczanie religii, s. 93.

${ }^{25}$ Z. KRASNODĘBSKI, Demokracja peryferii, wyd. 2, Wydawnictwo Słowo/Obraz Terytoria, Gdańsk 2005, s. 36, 59, 64, 227; A. Albert [czytaj W.S. RoszKowsKi], Najnowsza historia Polski 1914-1993, t. 2, Świat Książki, Warszawa 1995, s. 915; A. MıchNıK, Kościót - lewica - dialog, Biblioteka Gazety Wyborczej, Warszawa 2009, s. 231. 
silnie przywiązane do tradycji i wartości chrześcijańskich. Istotną rolę w społeczeństwie spełnia Kościół katolicki, który mając silną pozycję i autorytet oddziałuje na wiele wymiarów życia społecznego, w tym na wychowanie dzieci i młodzieży. Znaczna część społeczeństwa, należąca do Kościoła katolickiego, oczekiwała od elit politycznych, by w sferze publicznej były uznawane i szanowane przekonania wyznawców religii katolickiej. W dyskursie publicznym na temat obecności religii w szkole następowało zderzenie pogladów części polskiego społeczeństwa reprezentującego tradycyjne katolickie wartości z założeniami liberalnej demokracji promowanymi przez część wpływowych elit III RP ${ }^{26}$.

Dlatego też konflikt dotyczący powrotu lekcji religii do szkół w 1990 roku nie był spowodowany negatywnym nastawieniem społeczeństwa do tego faktu, ale miał swoje źródło w przekonaniach ideologicznych ówczesnych elit oraz w rywalizacji sił politycznych. Do postawienia takiej tezy skłania porównanie wyników badań sondażowych z początku lat dziewięćdziesiątych. Ukazują one poparcie dla katechezy szkolnej wyrażone przez ogół Polaków, młodzież oraz przez delegatów na zjazdy partii politycznych (Unii Demokratycznej, Kongresu Liberalno-Demokratycznego, Porozumienia Centrum).

W pierwszych latach po wprowadzeniu nauczania religii do szkół (19901992) Centrum Badania Opinii Społecznej prowadziło wśród dorosłych Polaków oraz młodzieży ostatnich klas szkół ponadpodstawowych badania socjologiczne dotyczące lekcji religii. Wyniki ogólnopolskich reprezentatywnych badań wskazywały, że około dwie trzecie respondentów opowiadało się za nauczaniem religii $\mathrm{w}$ szkole, natomiast jedna czwarta badanych była mu przeciwna. Proporcje te były podobne zarówno wśród zainteresowanej katechezą młodzieży jak i wśród dorosłych Polaków ${ }^{27}$.

Natomiast w przypadku elit politycznych poparcie dla katechezy szkolnej było zdecydowanie słabsze, co wykazały badania socjologiczne przeprowadzone wśród delegatów uczestniczących w kongresach partyjnych w latach 19911992. W roku 1991 najmniejsze poparcie dla wprowadzenia nauczania religii do szkół deklarowali przedstawiciele partii liberalnych ${ }^{28}$. Ludzie ci mieli silną pozycję w kręgach politycznych ówczesnej władzy, ponieważ po roku

\footnotetext{
${ }^{26}$ M. PILCH, Prawne aspekty nauczania religii i krzewienia religijności w szkołach publicznych, w: Obecność religii w publicznym systemie oświaty $w$ aspekcie prawnym, red. T.J. Zieliński, Wydawnictwo Naukowe ChAT, Warszawa 2012, s. 17 (17-61).

${ }^{27}$ M. GrabowsKa, Czy elity polityczne reprezentuja poglady społeczeństwa?, w: Nauka religii $w$ szkole $w$ świetle badań socjologicznych, s. 57.

${ }^{28}$ Tamże, s. 57-58.
} 
1989 liberalizm był forsowany jako najbardziej wpływowy nurt polityczny ${ }^{29}$. Decyzję o powrocie religii do szkół za słuszną uznawało $24 \%$ delegatów Unii Demokratycznej i $28 \%$ członków Kongresu Liberalno-Demokratycznego, natomiast rozwiązania tego nie popierało odpowiednio $65 \%$ i $57 \%$ badanych polityków z tych partii. Zdecydowanie lepiej wprowadzenie religii do szkół oceniali delegaci prawicowego Porozumienia Centrum, spośród których $68 \%$ akceptowało ten fakt, natomiast nie popierało go $28 \%$ respondentów. Podobne wyniki uzyskano podczas badań zrealizowanych na kongresach tych samych partii w 1992 roku. Około dwie trzecie badanych delegatów partii liberalnych Unii Demokratycznej i Kongresu Liberalno-Demokratycznego nie popierało decyzji o wprowadzeniu religii do szkół, a jedna czwarta uważała ją za słuszną. W badaniach nie uwzględniono deklaracji członków partii lewicowej - SdRP, zrzeszającej przede wszystkim ludzi dawnej nomenklatury, tj. postkomunistów ${ }^{30}$.

Liberałowie oraz postkomuniści, skupiający w swoich rękach środki masowego przekazu, silnie oddziaływali na opinię publiczną, ukazując religię w szkole jako zamach na świecki charakter szkoły publicznej. Oni też inspirowali publiczne debaty, w których podnoszono rzekomo niekonstytucyjny charakter lekcji religii w szkole. Zwolennicy liberalnej i lewicowej ideologii podjęli walkę światopoglądową z wartościami chrześcijańskimi stanowiącymi fundament moralny życia społecznego. Celem ich ataku stało się nie tylko nauczanie religii w szkole, ale również Kościół katolicki, który przedstawiali jako przeciwnika demokracji i nowoczesności oraz relikt tradycyjnej zaściankowości i zacofania ${ }^{31}$.

Przedstawione wyniki badań wskazują, że zarówno dorośli Polacy, jak i młodzież okazywali zdecydowanie większe poparcie dla wprowadzenia religii do szkół, aniżeli reprezentanci wpływowych wówczas liberalnych partii politycznych. Odmienne postawy badanych polityków oraz obywateli wskazują, że wybrani przez społeczeństwo politycy nie reprezentowali swoich wyborców w sprawach nauczania religii w szkole, ale kierowali się interesami partyjnymi lub własnymi przekonaniami. Elity polityczne, zajęte walką partyjną i ideologiczną, nie wsłuchiwały się w głos obywateli i zatraciły kontakt ze swoimi wyborcami, których mieli reprezentować. Sprzeciw wobec nauczania religii w szkole był elementem

${ }^{29}$ Z. KRASNODĘBSKI, Demokracja peryferii, s. 26; J. SZACKI, Liberalizm po komunizmie, s. 255-258.

${ }^{30}$ M. GRabowsKa, Czy elity polityczne?, s. 57-59.

${ }^{31}$ J. Gowin, Kościót w czasach wolności, s. 43; A. Albert, Najnowsza historia Polski, s. 880; Z. KRASNODĘBSKI, Demokracja peryferii, s. 36-38. 
walki ideologicznej prowadzonej z Kościołem katolickim, który wówczas oskarżano o próbę wprowadzania nowego totalitaryzmu ${ }^{32}$, budowanie państwa wyznaniowego $^{33}$, ideologizację przestrzeni publicznej ${ }^{34}$, a także opisywano jako przeciwnika demokracji i nowoczesności oraz relikt tradycyjnej zaściankowości i zacofania ${ }^{35}$. Liberałowie i postkomuniści przedstawiali Kościół katolicki podobnie jak niegdyś ukazywano „,czerwonych”36, czyli jako siłę przewodnią narodu dążącą do totalizacji życia społecznego ${ }^{37}$.

Postawy części polityków wobec wprowadzenia nauczania religii do szkół można uznać za przykład alienacji polityki, ukazujący napięcie między większością społeczeństwa akceptującą katechezę szkolną a elitami zaangażowanymi w ideologiczne spory. Wyobcowanie części elit politycznych w kwestii nauczania religii w szkole potwierdzają przedstawione poniżej wyniki badań dotyczące poparcia społecznego dla katechezy szkolnej, oceny jakości nauczania religii oraz frekwencji uczniów na lekcjach religii w polskich szkołach.

\section{POLACY O NAUCZANIU RELIGII W SZKOLE}

Z długoletnich badań socjologicznych wynika, iż powrót nauczania religii do szkół spotkał się z powszechnym poparciem ze strony uczniów i rodziców. W pierwszym roku nauczania religii w szkole (1990/91) w zajęciach uczestniczyło 95,8\% dzieci i młodzieży uczących się w polskich szkołach. W katechezie szkolnej najczęściej brali udział uczniowie szkół podstawowych (98,0\%) i liceów ogólnokształcących $(92,2 \%)$, nieco niższa frekwencja była w szkołach niepełnych średnich zawodowych $(89,7 \%)$ i średnich szkołach zawodowych $(88,5 \%)^{38}$. Katecheza w szkole została niemal powszechnie zaakceptowana przez rodziców dzieci szkół podstawowych, gdyż w miastach w lekcjach religii brało udział $97,3 \%$ dzieci, natomiast na wsi $99,3 \%{ }^{39}$.

32 A. DUDEK, Historia polityczna Polski, s. 156.

33 A. Michnik, Kościót - lewica - dialog, s. 231.

${ }^{34}$ H. ŚwIDA-ZIEMBA, Człowiek wewnętrznie zniewolony. Mechanizmy i konsekwencje minionej formacji - analiza psychospołeczna, Zakład Socjologii Moralności i Aksjologii Ogólnej, Instytut Stosowanych Nauk Społecznych Uniwersytet Warszawski, Warszawa 1997, s. 414.

${ }^{35}$ J. Gowin, Kościót w czasach wolności, s. 43.

36 J. SZACKI, Liberalizm po komunizmie, s. 236-237.

${ }^{37}$ H. ŚWIDA-ZIEMBa, Cztowiek, s. 416, 421.

${ }^{38}$ L. AdAMCZUK, Nauczanie religii w Polsce, s. 245.

${ }^{39}$ L. ADAMCZUK, Zasięg nauczania religii w szkołach polskich w 1991 r. w świetle danych 
Nauczanie religii w szkole miało również silne poparcie wśród dorosłych Polaków. W latach 1991-2008 ponad połowa badanych (53-65\%) uważała, że religia powinna być nauczana w szkole ${ }^{40}$.

Ogólnopolskie badania socjologiczne przeprowadzone w latach 1991-2016 na reprezentatywnej próbie młodzieży szkół średnich i zawodowych wskazują, że frekwencja na lekcjach religii do roku 2010 miała tendencję wzrostową. W roku 2010 r. osiągnęła najwyższa wartość (93\%). W kolejnych latach nastąiło odwrócenie trendu. W 2016 roku udział w katechezie szkolnej deklarowało $75 \%$ respondentów. Był to najsłabszy wynik od wprowadzenia nauczania religii do szkół publicznych. Pomimo że w ciągu sześciu lat prawie o jedną piątą zmniejszyła się częstotliwość uczestnictwa młodzieży w lekcjach religii, to jednak nadal zdecydowana większość młodych ludzi deklaruje, iż chodzi na zajęcia $\mathrm{z}$ religii ${ }^{41}$.

W innych badaniach w roku 2016 zaobserwowano spadek poparcia młodych ludzi dla przekonań prawicowych i większe sympatie dla wartości lewicowych. Zmiany te mogły mieć wpływ na mniejsze zainteresowanie religia w szkole ${ }^{42}$. Z drugiej strony polska młodzież wykazuje aktywność w sprawach religijnych, której potwierdzeniem był jej liczny udział w Światowych Dniach Młodzieży w 2016 roku z udziałem papieża Franciszka. Można przypuszczać, że zaangażowanie młodzieży w organizowanie uroczystości religijnych oraz wspólnotowa modlitwa wpłyną w przyszłości na większe zainteresowanie nauczaniem religii $\mathrm{w}$ szkole ${ }^{43}$.

Bardziej optymistyczne niż CBOS wskaźniki, odnoszące się do frekwencji na lekcjach religii, podają instytucje kościelne. Według danych statystycznych Komisji Episkopatu Polski ds. Wychowania Katolickiego w maju 2015 roku na zajęcia z religii uczęszczało 97\% uczniów szkół podstawowych, 95\% gimnazjalistów i 90\% uczniów szkół ponadgimnazjalnych. Z badań tych wynika, iż na lekcje religii przychodzi $94 \%$ ogółu uczniów kształcących się w polskich szkołach. Wraz z wiekiem młodych ludzi zwiększa się absencja

statystycznych, w: Szkoła czy parafia. Nauka religii w szkole w świetle badań socjologicznych, s. $17-21$.

${ }^{40}$ A. Potocki, O Kościelle także socjologicznie, s. 582.

${ }^{41}$ M. GwIAZDA, Religia w szkole - uczestnictwo i ocena, w: Młodziez 2016. Raport z badań, Centrum Badania Opinii Społecznej, Krajowe Biuro ds. Przeciwdziałania Narkomanii, Warszawa 2016, s. 141.

42 A. GŁowacki, Czy młodzi Polacy sa prawicowi, Komunikat z badań, nr 102/2017, Centrum Badania Opinii Społecznej, Warszawa 2017, s. 2-3.

${ }^{43}$ M. Bożewicz, Co pozostało po Światowych Dniach Młodzieży 2016, Komunikat z badań, nr 126/2016, CBOS, Warszawa 2016, s. 1-9. 
na katechezie szkolnej, gdyż najrzadziej uczestniczą w niej uczniowie szkół ponadgimnazjalnych ${ }^{44}$. W roku 2017 - według badań Instytutu Statystyki Kościoła Katolickiego - 76,3\% uczniów szkół ponadpodstawowych deklarowało swój udział w lekcjach religii. Najczęściej uczestniczyła w katechezie młodzież wiejska (84\%), natomiast najrzadziej przychodziła na nią młodzież z miast powyżej 500 tys. mieszkańców $(67 \%)$. W nauczaniu religii uczestniczyło $28 \%$ uczniów deklarujących się jako niewierzący ${ }^{45}$.

Stosunkowo wysoka frekwencja na lekcjach religii jest niewątpliwie wskaźnikiem dużego zainteresowania tymi zajęciami. Pokazuje nadto, iż w katechezie szkolnej biorą udział również uczniowie o słabo rozwiniętej wierze lub nawet niewierzący. Dlatego też nauczanie religii powinno być nastawione nie tylko na pogłębianie wiary, ale także na jej wzbudzanie przez ewangelizację u osób poszukujących Boga czy nawet niewierzących. Prawidłowo realizowana katecheza szkolna umożliwia dotarcie $\mathrm{z}$ ewangelicznym przesłaniem do młodych ludzi, którzy mimo, iż utracili kontakt z Kościołem instytucjonalnym, to jednak szukają spotkania $\mathrm{z}$ religią ${ }^{46}$.

Badania socjologiczne pokazują, iż uczestnictwo w nauczaniu religii związane jest ze stanem religijności młodzieży, a zwłaszcza z jej uczestnictwem w praktykach religijnych oraz z autodeklaracjami wiary. Uczniowie, którzy w roku 2016 regularnie, czyli przynajmniej raz w tygodniu brali udział w mszach czy nabożeństwach religijnych, niemal powszechnie przychodzili na katechezę (ok. 90\%). Wraz ze zmniejszaniem się częstotliwości udziału w praktykach religijnych obniżała się frekwencja na lekcjach religii. Spośród młodych ludzi, którzy tylko kilka razy w roku uczestniczyli w praktykach religijnych, 72\% partycypowało w nauczaniu religii. Podobne zależności występują pomiędzy udziałem w katechezie a autodeklaracjami wiary. Spośród uczniów deklarujących się jako głęboko wierzący i wierzący więcej niż cztery piąte $(84 \%)$ brało udział w katechezie. W przypadku osób niezdecydowanych, mających wątpliwości dotyczące wiary było to $68 \%$. Popularność katechezy wśród młodych ludzi potwierdza fakt, iż na lekcje religii uczęszczała nieco ponad połowa uczniów w ogóle niepraktykujących (52\%) oraz prawie połowa $(44 \%)$ deklarujących się jako niewierzacy ${ }^{47}$.

\footnotetext{
${ }^{44}$ Ł, KASPER, A. WOJTAS, Nauczanie religii $w$ szkole.

${ }^{45}$ KATOLICKA AGENCJA INFORMACYJNA, Nauczanie religii $w$ polskiej szkole, https://ekai. pl/nauczanie-religii-w-polskiej-szkole/ (dostęp 10.11.2018).

46 A. Potocki, O Kościele także socjologicznie, s. 567; I. CELARY, Nauczanie religii, s. 33-34.

${ }^{47}$ M. GwIAZDA, Religia w szkole, s. 144-145.
} 
Zmienną silnie różnicującą deklaracje dotyczące uczestnictwa w lekcjach religii jest miejsce zamieszkania badanej młodzieży. W 2016 roku najczęściej na katechezę chodziła młodzież zamieszkująca wioski (85\%). W porównaniu z rokiem 2013 nastąpił spadek o 11 punktów. Jeszcze większe zmniejszenie frekwencji w ciągu trzech lat miało miejsce wśród młodzieży zamieszkującej miasta poniżej 20 tysięcy. W roku 2013 udział w katechezie deklarowało 89\% badanych, natomiast w roku 2016 było to $72 \%$. Najbardziej dynamiczny spadek frekwencji w okresie trzech lat miał miejsce wśród młodzieży z największych miast (z $73 \%$ do $49 \%)^{48}$.

Zmniejszająca się częstotliwość uczestnictwa uczniów w nauczaniu religii jest skorelowana z przemianami religijności i moralności społeczeństwa polskiego. Oddzielanie religii od moralności zyskuje coraz więcej zwolenników wśród Polaków. W roku 2016 ponad 3/4 badanych (78\%) uważało, że religia nie musi uzasadniać nakazów moralnych. Za stwierdzeniem, że tylko religia może uzasadniać słuszne nakazy moralne opowiedziało się tylko $12 \%$ respondentów. Połowa badanych (49\%) jest przekonana, iż wychowanie w polskich szkołach powinno opierać się na ogólnoludzkim humanizmie odwołującym się do zasad uznawanych zarówno przez wierzących jak i niewierzących. Jedynie $14 \%$ respondentów uważało, że wychowanie w szkole powinno bazować na wartościach i normach wynikających z etyki katolickiej głoszonej przez Kościół ${ }^{49}$.

Nie ulega wątpliwości, iż obniżające się wskaźniki autodeklaracji wiary młodych ludzi, malejąca częstość ich udziału w praktykach religijnych oraz selektywne traktowanie moralności kościelnej ${ }^{50}$ wpływają na postawy wobec nauczania religii w szkole, które jest przez młodzież traktowane jako spotkanie o charakterze religijnym. Młodzież z wiosek i mniejszych miast, uczestnicząca najczęściej w katechezie szkolnej, upodabnia się do swoich rówieśni-

${ }^{48}$ R. Boguszewski, M. Feliksiak, M. Gwiazda, J. Kalka, Młodzież o sobie: wartości, obyczajowość, grupy odniesienia, w: Młodzież 2013, Opinie i diagnozy nr 28, red. M. Grabowska, J. Kalka, Centrum Badania Opinii Społecznej, Krajowe Biuro ds. Przeciwdziałania Narkomanii, Warszawa 2014, s. 119; M. GwIAZDA, Religia w szkole, s. 143.

49 R. BoguszewsKi, Zasady moralne a religia. Komunikat z badań, nr 4/2017, CBOS, Warszawa 2017, s. 4, 9.

${ }^{50}$ A. GŁowACKI, Religijność młodzieży, w: Młodzież 2016. Raport z badań, Centrum Badania Opinii Publicznej, Krajowe Biuro ds. Przeciwdziałania Narkomanii, Warszawa 2016, s. 131133; J. MARIAŃSKI, Młodzież między tradycja i ponowoczesnościa. Wartości moralne w świadomości maturzystów, Redakcja Wydawnictw Katolickiego Uniwersytetu Lubelskiego, Lublin 1995, s. 337; S.H. ZARĘBA, Dynamika świadomości religijno-moralnej młodzieży w warunkach przemian ustrojowych w Polsce (1988-1998), Zakład Wydawnictw Statystycznych, Warszawa 2003, s. 274-275. 
ków z dużych miast, którzy przejawiają słabsze zainteresowanie sprawami religijnymi i moralnymi. Zmiany te wskazuja na tendencje sekularyzacyjne młodego pokolenia ${ }^{51}$. Młodzi ludzie ulegają silnym prądom sekularyzacyjnym dominującym we współczesnych społeczeństwach europejskich. Wyzwalanie życia społecznego spod wpływu religii staje się celem działalności wielu instytucji i organizacji. Promują one laicki (świecki) styl życia wolny od wpływu religii i moralności konfesyjnej ${ }^{52}$.

Podobne tendencje sekularyzacyjne można dostrzec w działalności wielu mediów, zwłaszcza niechętnie nastawionych do Kościoła katolickiego. Zachęcają one Polaków, a zwłaszcza młodych ludzi do stylu życia wyzwolonego od religijnych czy moralnych wartości. Ponadto kreuja pejoratywny obraz Kościoła i duchowieństwa, mający destrukcyjny wpływ na wiarę młodzieży i podważający zaufanie do instytucji kościelnych. Szczególnym przejawem negatywnego ukazywania Kościoła są nadzwyczaj często „odgrzewane” (nawet sprzed kilkudziesięciu lat) sensacyjne wiadomości na temat pejoratywnych zachowań niektórych duchownych, mające sugerować, że w Kościele jest wiele zła i hipokryzji, gdyż instytucja wzywająca do zachowywania moralnych standardów, sama ich nie przestrzega. Podobne sugestie nietrudno znaleźć w promowanym ostatnio przez media filmie „Kler”, w którym wizerunek księży jest kreowany na przykładzie patologicznych zachowań kilku duchownych. Karykaturalne ukazanie kleru dyskredytuje religię katolicką, a zwłaszcza księży, którzy - rzekomo - nie dbając o dobro wiernych mają pogrążać się w własnych wadach, żądzach i permisywizmie moralnym ${ }^{53}$.

Utrzymująca się w polskich szkołach wysoka frekwencja uczniów na lekcjach religii jest powiązana z poparciem społecznym okazywanym katechezie w szkole. Przywrócenie nauczania religii do szkół spotkało się z przychylnymi reakcjami społeczeństwa. We wrześniu 1990 roku pozytywne emocje z powrotu lekcji religii do szkół wyrażało 61\% badanych Polaków (radość 33\% i zadowolenie $28 \%$ ). Obojętność wobec tego wydarzenia zadeklarowało $21 \%$ respondentów, natomiast niezadowolenie wyraziło $11 \%$ badanych. Tylko $2 \%$

${ }^{51}$ J. MARIAŃSKI, Przemiany moralności polskich maturzystów w latach 1994-2009. Studium socjologiczne, Wydawnictwo KUL, Lublin 2011, s. 447-448; S. H. ZARĘBA, W kierunku jakiej religijności? Studia nad katolicyzmem polskiej młodzieży, Zakład Wydawnictw Statystycznych, Warszawa 2008, s. 505-507; J. MARIAŃSKI, Megatrendy religijne w społeczeństwach ponowoczesnych. Studium socjologiczne, Wydawnictwo Adam Marszałek, Toruń 2016, s. 37-57.

52 J. PотоскI, O Kościele także socjologicznie, s. 388-389.

${ }^{53}$ W. JedynaK, Antyklerykalizm w natarciu, „Niedziela” 2018, nr 44, s. 23. 
respondentów ujawniło oburzenie z powodu decyzji o wprowadzeniu lekcji religii do szkót ${ }^{54}$.

Z ogólnopolskich badań socjologicznych zrealizowanych w latach 19912007 wynika, iż poparcie Polaków dla nauczania religii w szkole miało tendencję wzrostową. W roku 1991 za nauczaniem religii w szkole opowiadało się 57\% respondentów, natomiast w 2007 roku było to $72 \%$ badanych Polaków (wzrost o 15\%). W okresie tym zmniejszył się odsetek przeciwników katechezy w szkole (z $42 \%$ do $32 \%$ ). Badania socjologiczne zrealizowane w 2007 r. wskazują, że zwolennicy obecności katechezy w szkole przeważają we wszystkich badanych kategoriach społeczno-demograficznych. Najwyższe poparcie deklarują najmłodsi (od 18 do 24 lat) i najstarsi badani (65 lat i więcej), a więc uczniowie i studenci oraz emeryci. Badani Polacy zadeklarowali, że zdecydowanie bardziej cenią nauczanie religii, aniżeli lekcje z etyki. Połowa respondentów (50\%) wolałaby, aby ich dzieci uczęszczały w szkole na lekcje religii, co ósmy (13\%) wskazał etykę, natomiast jedna czwarta badanych $(26 \%)$ wybrałaby dla swoich dzieci zarówno religię jak i etykę $e^{55}$.

Wysokie poparcie społeczne dla nauczania religii w szkole pokazuje, iż Polacy aprobują tę formę edukacji religijnej dzieci i młodzieży. Zdecydowana większość polskiego społeczeństwa jest konsekwentna w kwestiach wiary i religijności, dlatego uważa, że młode pokolenie powinno zgodnie $\mathrm{z}$ własnymi przekonaniami otrzymywać formację religijno-moralną w szkołach, w których jest ono kształcone i wychowywane. Rodzice maja prawo decydować o wychowaniu swoich dzieci zgodnie z własnym światopoglądem oraz akceptowanym przez siebie systemem wartości. Wprawdzie część Polaków uważa, że szkoła nie zapewnia odpowiedniej atmosfery do prowadzenia zajęć z religii i dlatego lepszym rozwiązaniem byłaby katecheza w obiektach kościelnych, jednak zwolennicy takiego rozwiązania stanowią zdecydowaną mniejszość w polskim społeczeństwie.

Istotne znaczenie dla oceny procesu katechizacji w szkole mają wyrażane przez uczniów opinie na temat jakości nauczania religii. Z ogólnopolskich, reprezentatywnych badań socjologicznych wynika, iż pomimo zróżnicowania ocen dotyczących jakości nauczania religii w szkole najczęściej są one pozytywne.

W 1992 roku 36\% badanych uczniów twierdziło, że zajęcia z religii są ciekawe i dlatego chodzą na nie z ochotą, dla $39 \%$ lekcje religii niczym

\footnotetext{
${ }^{54}$ K. KoseŁA, Religia przy tablicy, s. 91.

${ }^{55}$ M. FeliKSIAK, Opinie o nauczaniu religii. Komunikat z badań, BS/119/2007, Centrum Badania Opinii Społecznej, Warszawa 2007, s. 3-4; http://www.cbos.pl/SPISKOM.POL/2007/K_ 119_07.PDF (dostęp 12.12.2017).
} 
szczególnym się nie wyróżniały, natomiast $25 \%$ młodych ludzi nudziło się na szkolnej katechezie. Po 11 latach (2003 r.) niewiele się zmieniło w ocenach uczniów, a analizowane wskaźniki miały odpowiednio następujące wartości: $41 \%, 34 \%$ i $25 \%$. Najbardziej krytycznie jakość katechezy oceniali uczniowie liceów ogólnokształcących (38\%), którzy twierdzili, że zajęcia są nudne i nic ważnego na nich się nie dzieje. Rzadziej zastrzeżenia wyrażali uczniowie techników (21\%). Najmniej uwag do treści katechezy i sposobu jej przekazywania mieli uczniowie liceów zawodowych (16\%) i zasadniczych szkół zawodowych $(16 \%)^{56}$.

W 2013 roku zadowolenie z udziału w katechezie szkolnej deklarowała jedna trzecia badanych (34\%). Osoby te uważały, że lekcje religii są prowadzone w sposób interesujący i dlatego chętnie na nie przychodzą. Dla $38 \%$ badanych katecheza nie różniła się niczym szczególnym od pozostałych przedmiotów szkolnych, natomiast nieco ponad jedna czwarta respondentów (28\%) twierdziła, iż lekcje religii są dla niej nudne, gdyż nic ważnego na nich się nie dzieje ${ }^{57}$.

W roku 2016 dwie piąte respondentów oceniało lekcje religii jako ciekawe, prawie tyle samo uczniów (38\%) twierdziło, że katecheza niczym szczególnym się nie wyróżnia i jest jak każda inna lekcja, natomiast niezadowolenie z zajęć deklarował nieco więcej niż co piąty uczeń (22\%). Porównanie wyników badań z lat 1992-2016 pokazuje, że oceny młodzieży odnoszące się do jakości nauczania katechezy były stabilne, gdyż stwierdzono jedynie nieznaczne, kilkuprocentowe zmiany.

Wydaje się, że stabilne oceny dotyczące jakości nauczania religii w szkołach są wynikiem realizowania przez katechetów jednakowych programów kształcenia oraz stosowania podobnych metod nauczania. Fakt, że prawie dwie piąte uczniów w okresie ćwierćwiecza uważało, że nauczanie religii wyróżnia się spośród innych przedmiotów i zaciekawia młodzież, jest istotnym atutem tych zajęć.

${ }^{56}$ B. Badora, M. Gwiazda, J. KalKa, G. ŚwiątKIEwicz, Młodzież 2003. Opinie i diagnozy nr 2, Centrum Badania Opinii Społecznej, Krajowe Biuro ds. Przeciwdziałania Narkomanii, Warszawa 2004, s. 51-52: file:///C:/Users/Wit/Downloads/M\%C5\%82odzie\%C5\%BC_2003. pdf (dostęp 11.12.2017).

${ }^{57}$ R. Boguszewski, M. Feliksiak, M. Gwiazda, J. KalKa, Młodzież o sobie, s. 125-126. Zob. K. BUlKowsKi, S. NowOtNY, W. SADŁOŃ, Statystyczny obraz religijności spoteczeństwa polskiego i szkolnej edukacji religijnej, w: Nauczanie religii $w$ szkole $w$ latach 1990-2015 wobec zadan katechezy, red. A. Rayzacher-Majewska, Wydawnictwo Uniwersytetu Kardynała Stefana Wyszyńskiego w Warszawie, Warszawa 2016, s. 209. 
Połowa badanych uczniów szkół ponadgimnazjalnych stwierdziła, że najlepszą formą nauczania religii są zajęcia nieobowiązkowe w szkole. Zdecydowanie mniej badanych (14\%) wybrało rozwiązanie, aby nieobowiązkowe nauczanie religii odbywało się $\mathrm{w}$ punktach katechetycznych przy parafiach. Za przeniesieniem religii do kanonu przedmiotów obowiązkowych w szkole opowiedziało się $17 \%$, natomiast obowiązkową katechezę w punktach katechetycznych poparło jedynie $2 \%$ respondentów. Zdania w tej kwestii nie miało $17 \%$ uczniów. Badania te wykazały, że $67 \%$ młodych ludzi popiera nauczanie religii w szkole (nieobowiązkowe i obowiązkowe), natomiast $16 \%$ jest za nauczaniem religii $\mathrm{w}$ obiektach parafialnych ${ }^{58}$.

Większość uczniów popiera lekcje religii w szkole, ponieważ może w nich uczestniczyć w ramach zajęć szkolnych. Uczniom i rodzicom łatwiej zaplanować organizację całodziennych obowiązków w sytuacji, gdy religia nauczana jest w szkole. Uczniowie oszczędzają czas, gdyż nie muszą udawać się na zajęcia pozalekcyjne do obiektów kościelnych. Aprobata dla powszechnego i łatwego dostępu do religii w szkole wydaje się być dla uczniów i rodziców czymś oczywistym.

\section{PODSUMOWANIE}

Po upadku komunizmu w Polsce nauczanie religii zostało w 1990 roku przywrócone do szkół publicznych. Spotkało się z powszechną akceptacją rodziców i uczniów, gdyż uczestniczyło w nim ponad 90\% młodych ludzi, kształcących się w polskich szkołach. Bardzo wysoka frekwencja na lekcjach religii była efektem przywiązania Polaków do religii katolickiej. Niezmiennie, od wielu lat ponad 90\% ogółu Polaków deklaruje się jako osoby wierzące należące do Kościoła katolickiego.

Obserwowany od kilku lat spadek uczestnictwa w katechezie szkolnej jest skutkiem tendencji sekularyzacyjnych zauważalnych zwłaszcza wśród młodego pokolenia Polaków. Pomimo zmniejszania się częstotliwości udziału młodzieży w lekcjach religii nadal zdecydowana większość uczniów chodzi na te zajęcia. Młodzi ludzie pozytywnie oceniają jakość katechezy, gdyż uważają, że lekcje są ciekawe lub nie różnią się od innych przedmiotów. Co czwarty uczeń twierdzi, że nudzi się na zajęciach z religii, ponieważ nic ważnego na

\footnotetext{
${ }^{58}$ M. GwiAZDA, Religia w szkole, s. 148.
} 
nich się nie dzieje. Stabilne oceny jakości katechezy szkolnej w okresie ćwierćwiecza wskazują na wyrównany poziom nauczania.

Niezmiennie, od początku lat dziewięćdziesiątych, większość dorosłych Polaków opowiada się za nauczaniem religii w szkole. Zarówno dla rodziców jak i dla uczniów lekcje religii w szkole ułatwiają organizację dnia pracy i nie obciążają młodych ludzi dodatkowymi zajęciami pozalekcyjnymi, realizowanymi poza szkołą. Przy wysokim poparciu społecznym dla nauczania religii w szkole, spory dotyczące obecności katechezy w szkole mają najczęściej charakter ideologiczny i polityczny, gdyż z reguły są inspirowane przez siły polityczne, nieprzychylnie nastawione do religii. Zdecydowana większość Polaków nie jest zainteresowana konfliktem o nauczanie religii w szkołach publicznych, o czym świadczy silne poparcie społeczne dla katechezy szkolnej i powszechny w niej udział uczniów.

\section{BIBLIOGRAFIA}

Albert A. [czytaj W.S. Roszkowski], Najnowsza historia Polski 1914-1993, t. 2, Świat Książki, Warszawa 1995.

ADAmCZuK L., Nauczanie religii w Polsce 1945-1999, w: Kościół i religijność Polaków 19451999, red. W. Zdaniewicz, T. Zembrzuski, Instytut Statystyki Kościoła Katolickiego SAC, Warszawa 2000, s. 223-251.

ADAMCZUK L., Zasięg nauczania religii w szkołach polskich w 1991 r. w świetle danych statystycznych, w: Szkoła czy parafia. Nauka religii w szkole w świetle badań socjologicznych, red. K. Kiciński, K. Koseła, W. Pawlik, Zakład Wydawniczy Nomos, Kraków 1995, s. $15-24$.

ANUSZ A., ANUSZ A., Samotnie wśród wiernych. Kościół wobec przemian politycznych w Polsce (1944-1994), Wydawnictwo Alfa, Warszawa 1994.

Badora B., Gwiazda M., Kalka J., ŚwiątKiewicz G., Młodzież 2003. Opinie i diagnozy nr 2, Centrum Badania Opinii Społecznej, Krajowe Biuro ds. Przeciwdziałania Narkomanii, Warszawa2004;file:///C:/Users/Wit/Downloads/M\%C5\%82odzie\%C5\%BC_2003.pdf(dostęp 11.12.2017).

BANIAK J., O nauczaniu religii i etyki w szkole, http://www.kulturaswiecka.pl/node/641 (dostęp 09.12.2017).

BEDNARCZYK R., Efektywność szkolnej lekcji religii w perspektywie „filarów wiary”, w: Nauczanie religii w szkole w latach 1990-2015 wobec zadań katechezy, red. A. RayzacherMajewska, Wydawnictwo Uniwersytetu Kardynała Stefana Wyszyńskiego w Warszawie, Warszawa 2016, s. 13-86.

BOBER S., Walka o utrzymanie nauczania religii w szkołach w okresie Polski Ludowej, ,Studia Ełckie" 14(2012), s. 189-200.

Boguszewski R., FeliKsiaK M., Gwiazda M., KALKa J., Młodzież o sobie: wartości, obyczajowość, grupy odniesienia, w: Młodzież 2013. Opinie i diagnozy nr 28, red. M. Grabowska, 
J. Kalka, Centrum Badania Opinii Społecznej, Krajowe Biuro ds. Przeciwdziałania Narkomanii, Warszawa 2014, s. 112-159.

BogUSZEWSKI R., Zasady moralne a religia. Komunikat z badań, nr 4/2017, CBOS, Warszawa 2017.

Bożewicz M., Co pozostało po Światowych Dniach Młodzieży 2016. Komunikat z badań, nr 126/2016, CBOS, Warszawa 2016.

BulKowski K., Nowotny S., SADŁoń W., Statystyczny obraz religijności społeczeństwa polskiego i szkolnej edukacji religijnej, w: Nauczanie religii w szkole w latach 1990-2015 wobec zadań katechezy, red. A. Rayzacher-Majewska, Wydawnictwo Uniwersytetu Kardynała Stefana Wyszyńskiego w Warszawie, Warszawa 2016, s. 171-215.

Celary I., Nauczanie religii w szkole szansą dla ewangelizacji młodzieży, „Perspectiva. Legnickie Studia Teologiczno-Historyczne" 10(2011), nr 1, s. 21-34.

CzeKALSKI R., Rys historyczny lekcji religii katolickiej w Polsce, „Studia Katechetyczne” 7(2010), s. 99-125.

Dudek A., Historia polityczna Polski 1989-2005, wyd. 1, Wydawnictwo Arcana, Kraków 2007.

DudeK A., GRYZ R., Komuniści i Kościół w Polsce (1945-1989), Wydawnictwo Znak, Kraków 2006.

EPISKOPAT POLSKI, Komunikat 240 Konferencji Plenarnej Episkopatu Polski (Warszawa, 2.05. 1990), w: Komunikaty Konferencji Episkopatu Polski 1945-2000, opr. J. Żaryn, Sekretariat Konferencji Episkopatu Polski, Pallottinum, Warszawa-Poznań 2006, s. 354-356.

EPISKOPAT POLSKI, List pasterski Episkopatu Polski w sprawie powrotu katechizacji do szkoły polskiej (Kraków, 16.06.1990), w: Listy pasterskie Episkopatu Polski 1945-2000, red. P. Libera, A. Rybicki, S. Łącki, cz. 2, Wydawnictwo Michalineum, Marki 2003, s. 1649-1653.

FELIKSIAK M., Opinie o nauczaniu religii. Komunikat z badań, BS/119/2007, Centrum Badania OpiniiSpołecznej, Warszawa2007; http://www.cbos.pl/SPISKOM.POL/2007/K_119_07.PDF (dostęp 12.12.2017).

GŁowaCKi A., Czy młodzi Polacy są prawicowi. Komunikat z badań, nr 102/2017, Centrum Badania Opinii Społecznej, Warszawa 2017.

GŁOWACKI A., Religijność młodzieży, w: Młodzież 2016. Raport z badań, Centrum Badania Opinii Społecznej, Krajowe Biuro ds. Przeciwdziałania Narkomanii, Warszawa 2016, s. $130-140$

Gowin J., Kościół w czasach wolności 1989-1999, Wydawnictwo Znak, Kraków 1999.

GRABOWsKA M., Czy elity polityczne reprezentują poglądy społeczeństwa?, Nauka religii w szkole w świetle badań socjologicznych, red. K. Kiciński, K. Koseła, W. Pawlik, Zakład Wydawniczy Nomos, Kraków 1995, s. 55-63.

GwiAZDA M., Religia w szkole - uczestnictwo i ocena, w: Młodzież 2016. Raport z badań, Centrum Badania Opinii Społecznej, Krajowe Biuro ds. Przeciwdziałania Narkomanii, Warszawa 2016, s. 141-152.

JEDYNAK W., Antyklerykalizm w natarciu, „Niedziela” 2018, nr 44, s. 22-23.

KASPER Ł., WoJTAS A., Nauczanie religii w szkole - zgodne z konstytucją i europejskimi standardami; http://www.katecheza.episkopat.pl/index.php/menu/nauczanie-religii-w-szkole /dokumenty-koscielne/104-nauczanie-religii-w-szkole-zgodne-z-konstytucja-i-europejskimistandardami-2016 (dostęp 08.12.2017).

KATOLICKA AGENCJA INFORMACYJNA, Nauczanie religii w polskiej szkole, https://ekai.pl/nau czanie-religii-w-polskiej-szkole/ (dostęp 10.11.2018).

KINAL M., Teaching of religion in polish schools after 1989, w: Sociology of Religion. Selected aspects from Central European Region, red. W. Jedynak, J. Kinal. D. Luźny, D. Topinka, Advert, Rzeszów 2016, s. 116-132. 
Konkordat między Stolicą Apostolską i Rzeczypospolitą Polską, podpisany w Warszawie dnia 28 lipca 1993 r., art 12, ust. 1-4 (Dz.U. 1998 nr 51 poz. 318); http://prawo.sejm.gov.pl/i sap.nsf/DocDetails.xsp?id=WDU19980510318 (dostęp 15.12.2017).

Konstytucja Rzeczpospolitej Polskiej z 2 kwietnia 1997 r., art. 53, ust. 4, (Dz.U. 1997 nr 78 poz.483;http://prawo.sejm.gov.pl/isap.nsf/download.xsp/WDU19970780483/U/D19970483Lj .pdf (dostęp 15.12.2017).

KosEŁA K., Religia przy tablicy - postawy wobec lekcji religii w szkołach, w: Szkoła czy parafia? Nauka religii w szkole w świetle badań socjologicznych, red. K. Kiciński, K. Koseła, W. Pawlik, Zakład Wydawniczy Nomos, Kraków 1995, s. 88-121.

KRASNODĘBSKI Z., Demokracja peryferii, wyd. 2, Wydawnictwo Słowo/Obraz Terytoria, Gdańsk 2005.

KRZYWKOWSKA J., Uregulowania prawne i praktyka w zakresie nauczania religii w szkołach publicznych w Polsce, „Studia Prawnoustrojowe” 2017, nr 38, s. 354-367.

LEPA A., Świat propagandy, wyd. 1, Tygodnik Katolicki „Niedziela”, Częstochowa 1994.

MARIAŃSKI J., Megatrendy religijne w społeczeństwach ponowoczesnych. Studium socjologiczne, Wydawnictwo Adam Marszałek, Toruń 2016.

MARIAŃSKI J., Młodzież między tradycją i ponowoczesnością. Wartości moralne w świadomości maturzystów, Redakcja Wydawnictw Katolickiego Uniwersytetu Lubelskiego, Lublin 1995.

MARIAŃSKI J., Przemiany moralności polskich maturzystów w latach 1994-2009. Studium socjologiczne, Wydawnictwo KUL, Lublin 2011.

MichniK A., Kościół - lewica - dialog, Biblioteka Gazety Wyborczej, Warszawa 2009.

MURZAŃSKI S., PRL - zbrodnia niedoskonała: rozważania o terrorze władzy i społecznym oporze, Oficyna Wydawnicza Volumen, Wydawnictwo Alfa-Wero, Warszawa 1996.

Osial W., Misja wychowawcza lekcji religii w szkole, „Warszawskie Studia Teologiczne” 25(2012), nr 2, s. 269-280.

PAWLIK W., Nauka religii w szkole jako problem polityczny, w: Szkoła czy parafia? Nauka religii w szkole w świetle badań socjologicznych, red. K. Kiciński, K. Koseła, W. Pawlik, Zakład Wydawniczy Nomos, Kraków 1995, s. 25-54.

PILCH M., Prawne aspekty nauczania religii i krzewienia religijności w szkołach publicznych, w: Obecność religii w publicznym systemie oświaty w aspekcie prawnym, red. T.J. Zieliński, Wydawnictwo Naukowe ChAT, Warszawa 2012, s. 17-61.

PISAREK M., Obecność nauczania religii w publicznym systemie oświaty w świetle obowiązującego prawa, Wydawnictwo i Drukarnia Diecezji Rzeszowskiej, Rzeszów 2013.

POTOCKI A., O Kościele także socjologicznie, Wydawnictwo Naukowe PWN, Warszawa 2017.

RAYZACHER-MAJEWSKA A., Wychowawcze zadania katechezy w szkolnym nauczaniu religii, w: Nauczanie religii w szkole w latach 1990-2015 wobec zadań katechezy, red. A. Rayzacher-Majewska, Wydawnictwo Uniwersytetu Kardynała Stefana Wyszyńskiego w Warszawie, Warszawa 2016, s. 87-167.

SkUZA S., Nauczanie religii w Polsce w świetle prawa państwowego po roku 1945, „Kolekcja Communio" 8(1993), s. 203-265.

SzACKI J., Liberalizm po komunizmie, wyd. 1, Społeczny Instytut Wydawniczy Znak, Fundacja im. Stefana Batorego, Kraków 1994.

SZPET J., Vademecum katechety, Księgarnia Świętego Wojciecha, Poznań 2000.

SzWAJKAJZER A., Młodzież o lekcjach religii w szkole, w: Szkoła czy parafia? Nauka religii w szkole w świetle badań socjologicznych, red. K. Kiciński, K. Koseła, W. Pawlik, Zakład Wydawniczy Nomos, Kraków 1995, s. 141-160. 
ŚWIDA-ZIEMBA H., Człowiek wewnętrznie zniewolony. Mechanizmy i konsekwencje minionej formacji - analiza psychospołeczna, Zakład Socjologii Moralności i Aksjologii Ogólnej. Instytut Stosowanych Nauk Społecznych. Uniwersytet Warszawski, Warszawa 1997.

TARNIEWSKI M. [czytaj Karpiński J.], Ewolucja czy rewolucja, Instytut Literacki, Paryż 1975.

TOKARZ G., Polska prasa lewicowa wobec Kościoła katolickiego w latach 1989-2002, b.w., Wrocław 2004.

TOMASIK P., Nauczanie religii w szkołach publicznych w Europie, „Studia Katechetyczne” 7(2010), s. 47-57.

TRZECiAK B., Relacja państwo-Kościół. O polskim Konkordacie '93, Oficyna Wydawnicza Kontrast, Warszawa 1998

TYMiEnIECKA A., Nauczanie religii w szkołach publicznych, „Kortowski Przegląd Prawniczy” 2015, nr 1, s. 92-96.

WIĘCEK K., Nauczanie religii katolickiej w polskiej szkole publicznej w kontekście prawa rodziców do wychowania religijnego dzieci - aspekty historyczne i wybrane aktualne problemy, „Studia z Prawa Wyznaniowego” 16(2013), s. 185-211.

ZARĘBA S.H., Dynamika świadomości religijno-moralnej młodzieży w warunkach przemian ustrojowych w Polsce (1988-1998), Zakład Wydawnictw Statystycznych, Warszawa 2003.

ZARĘBA S.H., W kierunku jakiej religijności? Studia nad katolicyzmem polskiej młodzieży, Zakład Wydawnictw Statystycznych, Warszawa 2008.

ZIELIŃSKI Z., Kościół w Polsce 1944-2002, Polskie Wydawnictwo Encyklopedyczne, Radom 2003.

\title{
NAUCZANIE RELIGII W SZKOLE W OPINIACH I OCENACH POLSKIEGO SPOŁECZEŃSTWA
}

\author{
S t r e s z c z e n i e
}

Przywrócenie nauczania religii do szkół publicznych w 1990 roku zostało zaakceptowane przez większość społeczeństwa polskiego. Jednak ze strony części sił politycznych podniosły się głosy sprzeciwu i oburzenia. Przeciwnicy powrotu lekcji religii do szkół twierdzili, że katechizacja w szkole narusza świecki charakter szkoły publicznej. Pomimo powracającej $\mathrm{z}$ różną częstotliwością i nasileniem krytyki nauczania religii w szkole większość polskiego społeczeństwa, w tym uczniów i rodziców, popiera obecność katechezy w szkole. Zdecydowana większość dzieci i młodzieży uczestniczy w lekcjach religii. Oceny dotyczące jakości nauczania religii w szkole są stabilne. Uczniowie deklarują, że chodzą na zajęcia z religii, gdyż są ciekawe lub nie różnią się od innych przedmiotów, część uczniów twierdzi jednak, że nudzi się na lekcjach religii.

Słowa kluczowe: nauczanie religii w szkole; katecheza w szkole; lekcje religii; uczniowie; spory o nauczanie religii $\mathrm{w}$ szkole. 
THE OPINION OF THE POLISH SOCIETY ON RELIGIOUS EDUCATION AT SCHOOL

\section{S u m m a r y}

The reintroduction of Religious Education to state schools in 1990 was accepted by the majority of the Polish society. However, it also met the objection and indignation of some of the political powers. The opponents of the idea thought that catechization at school breached a secular character of state schools. Despite the recurring criticism of RE teaching (of various frequency and intensity), the majority of the Polish society, including school goers and their parents, support catechization at school. The vast majority of children and youngsters participate in RE classes and the opinions on the quality of teaching are stable. School goers declare that they participate in the classes because they are interesting or because they treat RE like any other subject. Some of the school goers, however, think that the classes are boring.

Key words: Religious Education at school; catechization at school; RE classes; school goers; dispute over Religious Education at school. 